\title{
Effects of prepartum supplementation of $\beta$-carotene in Holstein cows
}

\author{
C. M. Prom, ${ }^{1} \odot$ M. A. Engstrom, ${ }^{2} \odot$ and J. K. Drackley ${ }^{1 *} \odot$ \\ ${ }^{1}$ Department of Animal Sciences, University of Illinois, Urbana 61801 \\ ${ }^{2}$ DSM Nutritional Products, LLC, Parsippany, NJ 07054
}

\begin{abstract}
Whether supplemental dietary $\beta$-carotene affects periparturient cows and vitamins $\mathrm{A}$ and $\mathrm{E}$ in cows when dietary vitamin $\mathrm{A}$ is adequate remains uncertain. Our objective was to assess the effect of $\beta$-carotene supplementation during the close-up dry period in a herd with adequate status of vitamins $\mathrm{A}$ and $\mathrm{E}$ but low in $\beta$-carotene. The study was conducted on a large commercial dairy farm in Indiana during early summer of 2015. Ninety-four multiparous Holstein cows were assigned to either control ( $\mathrm{CON} ; \mathrm{n}=47)$ or $\beta$-carotene $(\mathrm{BC} ; \mathrm{n}=47)$ treatments. When locked in headgates each morning, each cow received a topdress of $\beta$-carotene (Rovimix, $8 \mathrm{~g} / \mathrm{d}$; provided $800 \mathrm{mg}$ of $\beta$-carotene) or carrier from $21 \mathrm{~d}$ before expected calving until calving. Blood samples were collected at $21 \pm 1 \mathrm{~d}$ (mean \pm standard deviation) before expected calving (before treatments began), $7 \pm 1 \mathrm{~d}$ before calving, immediately following parturition, and $7 \pm 1 \mathrm{~d}$ postpartum. Blood serum was analyzed for vitamins $\mathrm{A}$ and $\mathrm{E}, \beta$-carotene, cholesterol, and other metabolites and enzymes. Data were analyzed using the MIXED procedure in SAS (SAS Institute Inc.). Cows had low $\beta$-carotene concentrations $(0.85 \mu \mathrm{g} / \mathrm{mL})$ in blood serum before treatments began. Compared with CON cows, BC cows had higher overall mean concentrations of $\beta$-carotene $(2.87 \mu \mathrm{g} / \mathrm{mL}$ vs. 0.73 $\mu \mathrm{g} / \mathrm{mL}$ ) and retinol (165 vs. $143 \mathrm{ng} / \mathrm{mL}$ ). Cows fed BC had lower $\alpha$-tocopherol in serum than cows fed CON (2.26 vs. $2.46 \mu \mathrm{g} / \mathrm{mL})$. Cows fed BC had lower peak milk than cows fed CON (50.9 vs. 55.3), but total lactation milk yield did not differ significantly. No effects of $\mathrm{BC}$ were observed on days to conception $(100 \mathrm{~d})$ or times bred (2.4). Treatments did not affect incidences of ketosis, retained placenta, displaced abomasum, off feed, lameness, footrot, mastitis, or metritis. In conclusion, in pregnant cows already receiving adequate vi-
\end{abstract}

Received October 25, 2021.

Accepted January 7, 2022.

*Corresponding author: drackley@illinois.edu tamin A but with low serum $\beta$-carotene concentration, supplementation of $\beta$-carotene increased concentrations of $\beta$-carotene and vitamin $\mathrm{A}$ in blood serum, but did not affect production, reproduction, or health.

Key words: carotenoid, transition cow, vitamin A, vitamin $\mathrm{E}$

\section{INTRODUCTION}

The transition period is a critical time for dairy cows (Drackley, 1999; Horst et al., 2021). Cows that are unable to adapt to negative energy balance can develop metabolic disorders, infectious diseases, and other health issues (Goff and Horst, 1997). Immunological activation during the prepartum period (Horst et al., 2021) may lead to increased production of reactive oxidative species (ROS), which, if in excess of antioxidant capabilities, can damage cellular structures (Machlin and Bendich, 1987; Albera and Kankofer, 2009). Although oxidative species are necessary to help defend against invading pathogens and dispose of potentially harmful compounds in the body, an excess of ROS can cause oxidative stress to the animal, leading to possible tissue damage and impaired function (Lykkesfeldt and Svendsen, 2007). Metabolic changes create additional oxidative stress to the animal, which then puts the animal more at risk for immunological and metabolic issues (Bernabucci et al., 2005). Around the time of parturition, metabolic activity in both cow and fetal calf increases, causing a surge of ROS and thus oxidative stress (Castillo et al., 2005; Albera and Kankofer, 2010). Any additional environmental, metabolic, or immunological stressors can further increase the amount of ROS and potentially overwhelm the antioxidant system. This vicious cycle can either be chased by managing the outcomes or be addressed more directly by way of antioxidants.

Three lipid-soluble, nonenzymatic antioxidants are vitamin $\mathrm{E}$, vitamin $\mathrm{A}$, and $\beta$-carotene. Vitamin $\mathrm{E}$ has long been known as a powerful antioxidant. Vitamin A primarily carries out nonantioxidative functions, such as epithelial maintenance and regulation of gene expression, and is not as robust of an antioxidant as 
vitamin $\mathrm{E}$ (Combs, 2008). $\beta$-Carotene is a dual-purpose compound, either acting as provitamin A or directly as an antioxidant. $\beta$-Carotene can be split into 2 retinol molecules and has long been supplemented as a source of vitamin $\mathrm{A}$. The efficiency of $\beta$-carotene conversion to retinol is greater when vitamin $\mathrm{A}$ is deficient (Combs, 2008). Research done in the 1970s began to reveal nonprovitamin functions of $\beta$-carotene associated with its antioxidant properties. Although the exact mechanisms remain unclear, $\beta$-carotene possesses immunomodulatory capabilities, possibly by way of scavenging singlet oxygen-suppressing peroxyl radicals (Chew, 1993; Chew and Park, 2004).

Exact mechanisms of how and when $\beta$-carotene's antioxidative activities occur, and especially how $\beta$-carotene interacts with vitamins $\mathrm{A}$ and $\mathrm{E}$, remain unclear. Responses to $\beta$-carotene supplementation have been inconsistent, possibly related to differences among studies in vitamin A status or $\beta$-carotene content of dietary ingredients. Some studies have failed to demonstrate a response of milk production to supplemental $\beta$-carotene (de Ondarza et al., 2009), whereas milk yield was increased in other studies (Aréchiga et al., 1998; Oldham et al., 1991). Hurley and Doane (1989) reported that supplemental $\beta$-carotene improved some measure of reproductive efficiency in most studies. Kaewlamun et al. (2011) reported that $1 \mathrm{~g} / \mathrm{d}$ of supplemental $\beta$-carotene had no effect on ovarian activity and uterine involution, despite the fact that Kawashima et al. (2009) reported anovulatory cows had lower concentrations of $\beta$-carotene in plasma. Some studies showed a relationship between low plasma concentrations of $\beta$-carotene prepartum and increased incidence of retained fetal membranes (Inaba et al., 1986; Akar and Gazioglu, 2006; Oliveira et al., 2015), whereas others did not (LeBlanc et al., 2004). One study (Chew, 1987) found that supplemental $\beta$-carotene decreased incidence of mastitis, but another study did not (Michal et al., 1994). Jukola et al. (1996) and Chew et al. (1982) reported increased mastitis in cows with low plasma $\beta$-carotene. Supplemental $\beta$-carotene decreased SCC in one study (Oliveira et al., 2015), whereas supplementing $425 \mathrm{mg}$ of $\beta$-carotene/d to lactating cows did not affect SCC in another study (de Ondarza et al., 2009). LeBlanc et al. (2004) found no relationship between $\beta$-carotene and intramammary infections. These conflicting data suggest that there are unseen variables at play that must be identified.

Our hypothesis was that prepartum supplementation of $\beta$-carotene to cows that were receiving adequate supplemental vitamins $\mathrm{A}$ and $\mathrm{E}$ would have beneficial effects on the transition to lactation and on reproductive efficiency. Thus, the objective of this research was to determine the effects of prepartum supplementation of $\beta$-carotene to cows with adequate vitamin $\mathrm{A}$ and $\mathrm{E}$ supplementation.

\section{MATERIALS AND METHODS}

\section{Description of Commercial Farm}

The research trial was conducted on a large commercial dairy farm in northern Indiana. The farm was selected for its large herd size, strict adherence to protocols, well-maintained computer records, and commitment to research. The facilities of particular interest included headlocks in the close-up pens, headlocks in the fresh pens, sanitary maternity area, and headlock with stand-alone milking setup in maternity area. Upon calving, cows were milked in the maternity area. Twice daily, newly-calved cows were transported by stock trailer to the fresh cow pens at the nearby main dairy site.

The herd consisted of approximately 7,000 cows in milk and 675 dry cows. The herd had an average 21-d pregnancy rate of $18 \%$ and an average 305-d mature equivalent milk yield of $\sim 14,000 \mathrm{~kg}$. Due to the size of the farm, 2 milking parlors were needed and the herd was thus split into 2 smaller herds. The 2 herds shared the feed storage area, which was located between the 2 parlors, and the employees split their time between the 2 herds. The same employee would mix the ration for the cows of both herds, the same team of employees would work with the fresh cows from both herds, and the same team of employees would complete treatments and surgeries for both herds. For computer-record purposes, the 2 herds were treated as 1, but could be sorted against each other using differing pen numbers. Despite the near-identical management and facilities, the herds themselves were treated as stand-alone herds with mixing of the cows between herds kept to a minimum. Different colored ear tags were used for each herd, and the daughters were kept in the respective herd of their dam. Similarly, at the dry cow facilities, there were 2 identical sets of freestall barns, separated by the central manure lagoons and maternity area. The dry cows were fed the same rations from the same feedstuffs mixed as one batch in the same wagon by the same employee. The employees at the dry cow facility performed their tasks on both herds without prejudice. Immediately before calving, cows from each herd would be channeled into the maternity area, where they could possibly be mixed with cows from the other herd. After calving, cows from both herds were kept in the same pen and hauled on the same stock trailer before being separated again at the milking site. Other than the maternity area, cows were rarely, if ever, exposed to cows from the other herd. 


\section{Selection of Cows for Trial}

Multiparous Holstein cows were selected based on their expected calving date during a calving window of June 29 to July 12, 2015. The 139 multiparous cows with expected calving dates within the desired window were first blocked by parity, then balanced by previous lactation milk yield. Cows then were assigned randomly to either the BC treatment or CON treatment. Ninetyfour Holstein cows with a mean parity of $2.4 \pm 0.63$ (mean $\pm \mathrm{SD}$ ), previous lactation milk yield of 12,610 \pm $5,690 \mathrm{~kg}$, dry period length of $52.5 \pm 4.45 \mathrm{~d}$, initial BCS of $3.2 \pm 0.5$, and a gestation length of $282.2 \pm 3.6 \mathrm{~d}$ completed the trial. These values did not differ between dietary treatment groups. Fifty-two of the cows were housed in one pen, and the remaining 42 animals were housed in another. Within each pen were cows that received $\mathrm{BC}$ and cows that received $\mathrm{CON}$.

\section{Management, Treatments, and Sampling}

All experimental procedures were approved by the University of Illinois Institutional Animal Care and Use Committee (protocol 15091). From June 8 to July 17, the cows in the close-up pens were locked in the headlocks (DaSilveira Southwest, Inc.) each morning at feeding time. The cows were locked up for less than $2 \mathrm{~h}$ daily, with the goal being less than $1 \mathrm{~h}$ when possible.

Cows were enrolled on trial $21 \mathrm{~d}$ prior $(\mathrm{d}-21)$ to expected calving date. On the enrollment date, each cow was assigned a BCS according to the system published by Ferguson et al. (1994) and had a small colored ear tag (Destron Fearing), blue for $\beta$-carotene supplementation (BC) and purple for control (CON), attached to the bottom corner of their existing ear tag. Cows were then given their first supplementation dose, either $\mathrm{CON}$ or $\mathrm{BC}$, and blood samples were taken from the caudal vein into 2 10-mL evacuated serum separation tubes (Becton Dickinson). Following sample collection, serum tubes were protected from light until processed.

The CON treatment consisted of $50 \mathrm{~g}$ of cracked corn, $50 \mathrm{~g}$ of dry molasses flakes (Dri-Mol, Archer Daniels Midland), $50 \mathrm{~g}$ of shredded beet pulp (Midwest AgriCommodities), and $25 \mathrm{~g}$ of yeast culture (Diamond $\mathrm{V}$ $\mathrm{XPC}$ ). The $\mathrm{BC}$ treatment was the same as $\mathrm{CON}$ with the addition of $8 \mathrm{~g}$ of Rovimix $\beta$-carotene (DSM), which is $10 \% \beta$-carotene (equating to $800 \mathrm{mg}$ of supplemental $\beta$-carotene). The $\beta$-carotene dose was determined by reviewing previous research and manufacturer recommendations. Treatment mixtures were formulated to maximize palatability and still provide a sufficient carrier blend for the $\beta$-carotene supplement. The mixtures were weighed daily using a digital scale into liter-sized plastic bags that had differing color zip tops for the $\mathrm{CON}$ and $\mathrm{BC}$ treatments.

The treatments were fed as a topdress to the cows while they were locked in headlocks each day. The cows received the topdress from $-21 \mathrm{~d}$ from predicted calving until calving. The actual length of time cows received treatments was $20.2 \pm 2.8 \mathrm{~d}$. Topdresses were placed on top of the TMR each morning within $2 \mathrm{~h}$ of the TMR being placed in front of the cows. The TMR was mixed and fed according to the farm's protocols. A small divot was made on top of the TMR pile in front of each cow, and the contents of the appropriate bag were carefully expelled into the divot. Each cow was observed to ensure they did not disperse the topdress into their TMR and that the neighboring cows did not consume any of the topdress. Any neighboring cows that were not easily dissuaded from consuming the topdress were released from their headlock, and the headlock was locked in the closed position so no cows could re-enter that space. The cows were scored each day on the amount of topdress consumed as described in Figure 1.

If topdress consumption was scored $\leq 2$, that cow was fed an additional dose of topdress the following day (i.e., 2 doses). Failure of the cow to consume most of the topdress (score $\leq 3$ ) for $3 \mathrm{~d}$ consecutively resulted in the cow being removed from trial to ensure that cows used for analyses maintained desired serum $\beta$-carotene concentrations throughout the topdress period. Cows were given these 3 chances because $\mathrm{BC}$ is fat-soluble and is stored by the body, making it unnecessary to be consumed every day. According to research at the University of Florida, a single dose of $\beta$-carotene can cause an increase in the concentration of $\beta$-carotene in serum that persists for several days following consumption (C. Staples, University of Florida, Gainesville, personal communication, July 7, 2016). Of the 139 cows that began the experiment, 40 cows (23 from the $\mathrm{BC}$ group and 17 from the CON group) were removed from trial due to failure of sufficient topdress consumption. If cows consumed the treatment for fewer than $14 \mathrm{~d}$ before calving, meaning they calved more than 7 $\mathrm{d}$ early, they were removed from the trial. They were also removed from trial if they calved more than $7 \mathrm{~d}$ late. Two cows (both from the BC group) were removed from trial for calving early and 3 (2 from CON group and 1 from BC group) were removed for calving late. No more samples were collected from any cows removed from trial. A total of 94 cows (47 from each treatment) completed the experiment.

In addition to $\mathrm{d}-21$, caudal blood draws, using 2 serum tubes as described above, were performed at 7 $\pm 1 \mathrm{~d}(\mathrm{~d}-7)$ before calving, within $2 \mathrm{~h}$ of calving (d 


\begin{tabular}{|l|l|l|l|l|}
\hline \multicolumn{5}{|c|}{ Topdress consumption scores } \\
\hline 0 & 1 & 2 & 3 & 4 \\
\hline $\begin{array}{l}\text { Did not consume } \\
\text { any }\end{array}$ & $\begin{array}{l}\text { Did not consume } \\
\text { a substantial } \\
\text { amount, but } \\
\text { exhibited licking } \\
\text { behavior }\end{array}$ & $\begin{array}{l}\text { Consumed } \\
\text { roughly half }\end{array}$ & $\begin{array}{l}\text { Consumed } \\
\text { almost all }\end{array}$ & $\begin{array}{l}\text { Consumed } \\
\text { completely }\end{array}$ \\
\hline
\end{tabular}
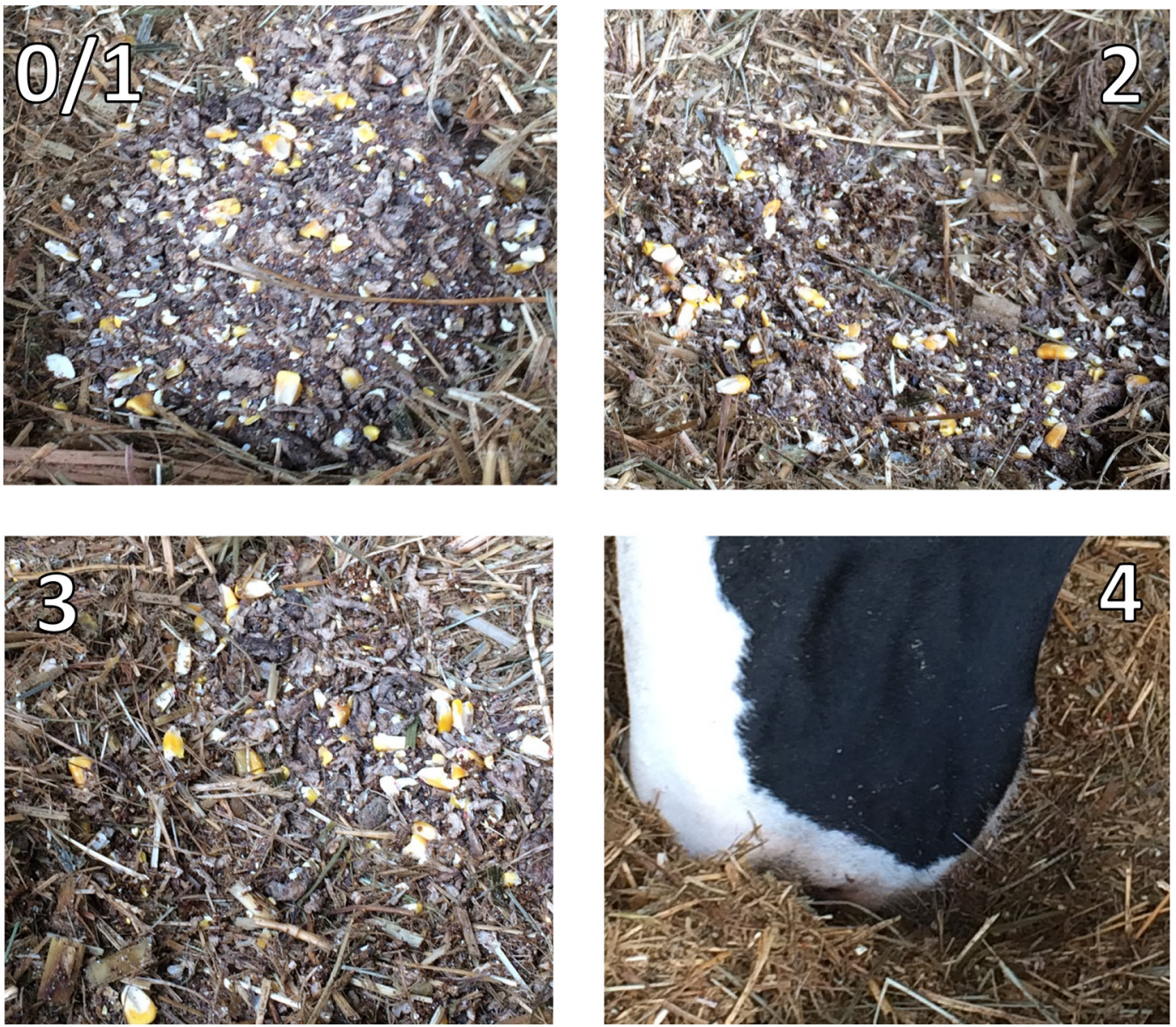

Figure 1. Visual descriptions of scores given for topdress consumption.

0 ), and $7 \pm 1 \mathrm{~d}$ following calving ( $\mathrm{d} 7)$. The $\mathrm{d}-21$ and $\mathrm{d}-7$ blood draws were performed during the morning lock-up period, whereas d 0 blood draw was performed at time of colostrum collection, within $2 \mathrm{~h}$ of parturition. Similarly, d 7 blood samples were taken during the time period that the fresh cow management team locked the fresh cows up each morning. Following the d 7 blood draw, the cow was assigned a BCS and the treatment ear tag was removed.

The cows were cared for by the farm staff according to their protocols. Cows calved on clean straw in a pen that was sanitized regularly and were milked within $2 \mathrm{~h}$ of calving. Disease incidence, treatments, and reproductive status were entered into DairyComp 305 (Valley Agricultural Software) by the farm staff. Calving difficulty was determined by the research team after conferring with farm staff based on the system developed by the University of Minnesota. The scoring system was as follows: 1 = no problem (unobserved or less than $2 \mathrm{~h}$ ), 2 = slight problem (greater than $2 \mathrm{~h}$, but no assistance provided), $3=$ needed assistance (hand pull), $4=$ difficult pull (obstetrical chains with consid- 
erable force), and $5=$ extreme difficulty (mechanical puller or cesarean section).

Cows were assigned a BCS by one trained individual at the $\mathrm{d}-21$ and $\mathrm{d} 7$ blood draws, and change in BCS was calculated as $\mathrm{d}-21$ minus $\mathrm{d} 7$. Cow production and health variables were retrieved from a DairyComp backup obtained approximately $1 \mathrm{yr}$ after the beginning of the trial, including parity, number of days dry, calving date, days open before being rebred, times bred, reproductive status, whether they left the herd, 305-d milk yield (calculated from daily milk yields), milk yield at d 28 postpartum, days at peak milk yield, and milk yield at peak. Data for peak milk were available from $43 \mathrm{CON}$ cows and $42 \mathrm{BC}$ cows, data for 305-d milk were available from 34 cows on each treatment, and reproductive data were available from $38 \mathrm{CON}$ cows and $32 \mathrm{BC}$ cows. In addition, data for the presence or absence of displaced abomasum, off feed, ketosis, lameness, footrot, mastitis, metritis, milk fever, and retained placenta were available from the records. Displaced abomasum was diagnosed by the veterinarian, off feed was defined as a cow without normal rumen fill, ketosis was determined by urine test strips during the first 10 DIM while in lockups, metritis was defined as abnormal vaginal discharge during the first 10 DIM, milk fever was a cow in recumbency that responded to i.v. Ca therapy, and retained placenta was the presence of placenta at $24 \mathrm{~h}$ after calving.

\section{Feed Samples}

Feed samples were obtained on a weekly basis. For the close-up cows, samples were gathered from untouched TMR and refused TMR, corn silage, hay, and premix pellets. During the weeks in which trial cows were in the fresh pens, samples were taken similarly from their TMR and corn silage. Composite samples were formed from 3 consecutive weekly samples for analysis.

\section{Sample Processing and Analysis}

Within $2 \mathrm{~h}$ of blood collection, the 2 serum tubes were centrifuged with a HN-SII centrifuge (Damon IEC) at $1,300 \times g$ for $15 \mathrm{~min}$ at room temperature. The serum was pipetted into 5 -mL polystyrene tubes (Globe Scientific) and stored at $-20^{\circ} \mathrm{C}$ in the on-farm chest freezer. Periodically throughout the study, frozen samples were transported on ice by car back to the University of Illinois where they were again stored at $-20^{\circ} \mathrm{C}$. Serum samples were delivered on ice to the Diagnostic Center for Population and Animal Health at Michigan State University (East Lansing, MI) for HPLC analysis of retinol, $\alpha$-tocopherol, $\beta$-carotene, and cholesterol. Serum samples were also analyzed by the University of Illinois College of Veterinary Medicine Diagnostic Laboratory (Urbana, IL) for metabolites and enzymes by automated enzymatic analysis. Analytes included creatinine, urea $\mathrm{N}$, total protein, albumin, globulin, $\mathrm{Ca}$, $\mathrm{P}, \mathrm{Mg}, \mathrm{Na}, \mathrm{K}, \mathrm{Cl}$, glucose, total alkaline phosphatase (AP), aspartate aminotransferase (AST), gamma-glutamyl transpeptidase (GGT), total bilirubin, creatine phosphokinase, total cholesterol, glutamate dehydrogenase (GLDH), bicarbonate, and triglycerides. Assays for nonesterified fatty acids (NEFA), and BHB (Wako Diagnostics) were performed in-house.

Following collection, the TMR samples were processed through a Penn State Particle Separator and weighed according to the protocol published by Pennsylvania State University (State College, PA). All feed samples were then frozen at $-20^{\circ} \mathrm{C}$ in the on-farm freezer and later transported back to the campus freezer. Samples were composited and then sent to Diagnostic Center for Population and Animal Health for vitamin analysis and to Dairy One (Ithaca, NY) for wet chemistry analysis. Procedures can be found at https://dairyone.com/ download/forage-forage-lab-analytical-procedures/.

\section{Statistical Analysis}

Cow was considered the experimental unit because treatments were applied individually to cows during feeding. Cows from both treatments were housed in the same pen, and pen was replicated so that environmental effects could be adequately accounted for in the statistical models. The collected data were divided into serum, production, and health data sets with each then analyzed using models developed in SAS 9.4 (SAS Institute Inc.).

We used PROC UNIVARIATE on each combination of variable, time point, and treatment assignment to examine residual plots and Shapiro-Wilk test statistics for normality. Outliers greater than 5 standard deviations from the median were removed. Following deletion of extreme outliers, the Brown-Forsythe test in PROC GLM was used to test each variable for equal variances. Transformations were not performed to obtain normality, but were performed where necessary to achieve homogeneous variances. Log-transformations were executed on GLDH from the cow serum data set and BCS from cow health data. Additionally, a square transformation was executed on GGT from the serum data set.

Continuous variables were used to construct mixed models for a complete randomized design with repeated measures in PROC MIXED, and ANOVA was examined for each variable. Parity, treatment, and time as well as all their interactions were included as fixed effects. Pen number of the cow was also included as a fixed 
effect. Cow was designated as a random effect. Covariance structures tested were compound symmetry and autoregressive type 1, and the latter was used for the data. Parity was included in the model due to known milk yield and vitamin differences by parity. Of the 94 cows used for the trial, 61 were beginning their second lactation (29 for $\mathrm{BC}$ and 31 for $\mathrm{CON}$ ), 26 were beginning their third lactation (15 for $\mathrm{BC}$ and 12 for $\mathrm{CON}$ ), and 7 were beginning their fourth lactation ( 3 for $\mathrm{BC}$ and 4 for CON). Data from date of enrollment $(\mathrm{d}-21)$ were used as a covariate for the cow serum data. Binary values from the cow health data set were analyzed using PROC GLIMMIX, with a value of 1 representing that they were pregnant, sick, or sold depending on the variable, and a value of 0 representing the opposite. Reproductive values were analyzed at a cut-off point of 120 DIM, whereas health values were analyzed using data from $\leq 30$ DIM. Correlations between variables were calculated using PROC CORR. Statistical tests were deemed as significant when $P<0.05$ and as trending toward significance when $0.05<P<0.10$.

\section{RESULTS}

\section{Diet Composition and Vitamin Content in Feeds and Rations}

Ingredient formulation of the close-up and fresh diets is shown in Table 1. Pen DM feeding rates were 12.7 $\mathrm{kg} / \mathrm{d}$ per cow during the close-up period and $18.1 \mathrm{~kg} / \mathrm{d}$ per cow for the fresh pen. Analyzed composition of the diets is shown in Table 2. Results for the vitamins found in the tested ingredients and TMR are reported

Table 1. Diets (\% DM basis) for close-up dry cows and fresh lactating cows $^{1}$

\begin{tabular}{lcc}
\hline Ingredient & Close-up cows & Fresh cows \\
\hline Corn silage & 29.1 & 28.8 \\
Wheat straw & 18.6 & - \\
Alfalfa silage & - & 4.6 \\
Canola meal & 14.7 & 9.4 \\
Prairie grass hay & - & - \\
Alfalfa bale silage & 11.1 & 6.4 \\
Premix & 6.4 & 7.9 \\
Ground corn & - & 15.0 \\
Hominy & - & 6.7 \\
Rye silage & - & 4.6 \\
Whole fuzzy cottonseed & - & 4.0 \\
Corn gluten meal & - & 3.8 \\
Soybean meal & 3.6 & 3.2 \\
Marshmallow & 5.5 & - \\
Previous day orts & -1 \\
Alfalfa hay, western & & 3.1 \\
\hline
\end{tabular}

${ }^{1}$ Water was added at $28.6 \%$ of the DM and $25.1 \%$ of the DM fed for close-up and fresh cows, respectively.
Table 2. Analyzed chemical composition of TMR for close-up dry cows and fresh lactating cows ${ }^{1}$

\begin{tabular}{|c|c|c|c|}
\hline Component $^{2}$ & Unit & Close-up & Fresh \\
\hline DM & $\%$ as fed & 49.2 & 49.3 \\
\hline $\mathrm{CP}$ & $\%$ of DM & 15.6 & 16.4 \\
\hline ADICP & $\%$ of DM & 1.15 & 1.00 \\
\hline Soluble protein & $\% \mathrm{CP}$ & 34.0 & 38.0 \\
\hline NDICP & $\%$ of DM & 2.8 & 2.6 \\
\hline $\mathrm{ADF}$ & $\%$ of DM & 29.4 & 22.7 \\
\hline aNDFom & $\%$ of DM & 45.4 & 32.2 \\
\hline Lignin & $\%$ of DM & 5.3 & 4.2 \\
\hline NFC & $\%$ of DM & 28.3 & 38.0 \\
\hline Starch & $\%$ of DM & 18.2 & 22.7 \\
\hline $\mathrm{ESC}$ & $\%$ of $\mathrm{DM}$ & 4.6 & 4.5 \\
\hline Crude fat & $\%$ of DM & 3.45 & 5.00 \\
\hline Ash & $\%$ of $\mathrm{DM}$ & 9.28 & 8.51 \\
\hline $\mathrm{NE}_{\mathrm{L}}{ }^{3}$ & Mcal/kg & 1.45 & 1.70 \\
\hline $\mathrm{Ca}$ & $\%$ of DM & 1.27 & 0.87 \\
\hline $\mathrm{P}$ & $\%$ of DM & 0.34 & 0.41 \\
\hline $\mathrm{Mg}$ & $\%$ of DM & 0.48 & 0.38 \\
\hline $\mathrm{K}$ & $\%$ of $\mathrm{DM}$ & 1.11 & 1.50 \\
\hline $\mathrm{S}$ & $\%$ of DM & 0.43 & 0.28 \\
\hline $\mathrm{Cl}$ & $\%$ of $\mathrm{DM}$ & 0.88 & 0.58 \\
\hline $\mathrm{Na}$ & $\%$ of DM & 0.09 & 0.53 \\
\hline $\mathrm{Fe}$ & $\mathrm{mg} / \mathrm{kg}$ & 725 & 360 \\
\hline $\mathrm{Zn}$ & $\mathrm{mg} / \mathrm{kg}$ & 125 & 260 \\
\hline $\mathrm{Cu}$ & $\mathrm{mg} / \mathrm{kg}$ & 30 & 29 \\
\hline $\mathrm{Mn}$ & $\mathrm{mg} / \mathrm{kg}$ & 145 & 150 \\
\hline Mo & $\mathrm{mg} / \mathrm{kg}$ & 1.4 & 1.4 \\
\hline $\mathrm{DCAD}^{4}$ & $\mathrm{mEq} / 100 \mathrm{~g}$ & -20 & 28 \\
\hline
\end{tabular}

${ }^{1}$ Average of 2 composite samples of 3 wk each.

${ }^{2} \mathrm{ADICP}=$ acid detergent-insoluble $\mathrm{CP} ; \mathrm{NDICP}=$ neutral detergentinsoluble $\mathrm{CP}$; aNDFom = amylase-treated NDF expressed on an $\mathrm{OM}$ basis; ESC = ethanol-soluble carbohydrates.

${ }^{3}$ Calculated according to NRC (2001).

${ }^{4}$ Calculated as $(\mathrm{Na}+\mathrm{K})-(\mathrm{Cl}+\mathrm{S})$.

in Table 3. Chemical composition of orts (observed/ predicted) and particle size distribution of orts (data not shown) revealed no evidence of ration sorting.

\section{Constituents in Serum}

The results of the analyses on the cow serum are presented in Table 4 . There was a treatment effect with no treatment by parity interaction for $\beta$-carotene $(P$ $<0.01$ ). Overall, $\beta$-carotene concentration of supplemented cows was $2.87 \mu \mathrm{g} / \mathrm{mL}$ compared with 0.73 $\mu \mathrm{g} / \mathrm{mL}$ for control cows. At $\mathrm{d}-21$, before receiving supplementation, the herd average was $0.85 \mu \mathrm{g} / \mathrm{mL}$. The treatment by day interaction $(P<0.01)$ showed that by $\mathrm{d}-7$, the mean concentration for the supplemented cows had increased to $3.36 \mu \mathrm{g} / \mathrm{mL}$, with the peak of $3.55 \mu \mathrm{g} / \mathrm{mL}$ at $\mathrm{d} 0$. In contrast, the concentrations in the nonsupplemented cows never went beyond $0.88 \mu \mathrm{g} / \mathrm{mL}$, which was measured at $\mathrm{d}-7$. The lowest $\beta$-carotene concentrations occurred at $\mathrm{d} 7$, with values of $1.70 \mu \mathrm{g} / \mathrm{mL}$ and $0.59 \mu \mathrm{g} / \mathrm{mL}$ for BC and CON cows, respectively. 
Table 3. Vitamin (vit) concentrations in sampled feedstuffs (DM basis)

\begin{tabular}{|c|c|c|c|c|c|c|c|c|c|c|}
\hline Sample & $\begin{array}{c}\beta \text {-Carotene } \\
(\mathrm{mg} / \mathrm{kg})\end{array}$ & $\begin{array}{c}\text { Mean } \\
(\mathrm{mg} / \mathrm{kg})\end{array}$ & $\begin{array}{l}\text { Vit } \\
(\mathrm{IU} / \mathrm{kg})\end{array}$ & $\begin{array}{c}\text { Mean } \\
(\mathrm{IU} / \mathrm{kg})\end{array}$ & $\begin{array}{c}\alpha \text {-Tocopherol } \\
(\mathrm{mg} / \mathrm{kg})\end{array}$ & $\begin{array}{c}\text { Mean } \\
(\mathrm{mg} / \mathrm{kg})\end{array}$ & $\begin{array}{l}\text { Vit A activity }{ }^{2} \\
(\mathrm{IU} / \mathrm{kg})\end{array}$ & $\begin{array}{c}\text { Mean } \\
(\mathrm{IU} / \mathrm{kg})\end{array}$ & $\begin{array}{l}\text { Retinol } \\
(\mu \mathrm{g} / \mathrm{kg})\end{array}$ & $\begin{array}{c}\text { Mean } \\
(\mu \mathrm{g} / \mathrm{kg})\end{array}$ \\
\hline \multicolumn{11}{|l|}{ Close-up } \\
\hline Silage, wk 1-3 & 5.31 & 4.41 & 0.6 & 0.5 & 0.57 & 0.48 & $-^{3}$ & - & $ـ^{3}$ & - \\
\hline Hay, wk $1-3$ & 5.87 & 3.87 & 5.2 & 5.15 & 4.75 & 4.68 & - & - & - & - \\
\hline Hay, wk 4-6 & 1.86 & & 5.1 & & 4.60 & & - & - & - & - \\
\hline Pre-mix & 0.49 & 0.49 & 54.6 & 54.6 & 49.7 & 49.7 & 7,060 & 7,060 & 2,120 & 2,120 \\
\hline Silage & 5.13 & 5.13 & 0.5 & 0.5 & 0.42 & 0.42 & - & - & - & - \\
\hline TMR & 1.64 & 1.64 & 28.0 & 28.0 & 25.4 & 25.4 & 14,500 & 14.500 & 4,366 & 4,366 \\
\hline
\end{tabular}

${ }^{1} 1 \mathrm{IU}=0.9 \mathrm{mg}$ of R,R,R- $\alpha$-tocopherol.

${ }^{2} 1 \mathrm{IU}=0.3 \mu \mathrm{g}$ of retinol.

${ }^{3}$ Corn silage and hay not tested for vit A due to no pre-formed retinol being found in forages.

Retinol concentrations by treatment and day are shown in Table 4 . The treatment effect was significant $(P=0.002)$. Before supplementation, the serum retinol average of the cows sampled was $247 \mathrm{ng} / \mathrm{mL}$, and fell to its nadir at d 0 of $140 \mathrm{ng} / \mathrm{mL}$ for supplemented cows and $109 \mathrm{ng} / \mathrm{mL}$ for control cows. The significant parity effect demonstrated that vitamin A was greater for parity 2 cows $(170 \mathrm{ng} / \mathrm{mL})$ than for parity $\geq 3$ cows $(143$ $\mathrm{ng} / \mathrm{mL})$.

The dynamics of cow serum $\alpha$-tocopherol by treatment and day are shown in Table 4. $\alpha$-Tocopherol was lower for BC cows $(2.26 \mu \mathrm{g} / \mathrm{mL})$ than for CON cows $(2.46 \mu \mathrm{g} / \mathrm{mL})$. Concentrations decreased from $\mathrm{d}-21$ to d $7(2.96$ vs. $1.70 \mu \mathrm{g} / \mathrm{mL})$. The $\alpha$-tocopherol concentration was greater for parity 2 cows than for parity $\geq 3$ $(2.53$ vs. $2.19 \mu \mathrm{g} / \mathrm{mL})$. When normalized to cholesterol concentrations, the ratio of vitamin E:cholesterol was lower for $\mathrm{BC}$ cows than for $\mathrm{CON}(P=0.002)$. The ratio decreased from $\mathrm{d}-7$ to $\mathrm{d} 7$ and was greater $(P=0.004)$ for parity 2 cows (2.35) than for parity $\geq 3$ cows (2.19).

Concentrations of glucose, NEFA, cholesterol, and triglycerides were not affected by treatment (Table 4). Concentrations of NEFA and cholesterol were greater, and concentration of glucose was lower, for parity $\geq 3$ than for parity 2. Concentration of BHB was not affected by treatment but was greater for parity $\geq 3$ cows than for parity 2 cows (530 vs. $427 \mu \mathrm{mol} / \mathrm{L}$, respectively).

Concentration of creatinine was lower for cows fed $\mathrm{BC}$ than for those fed CON, and tended $(P=0.10)$ to be affected by a treatment by parity interaction. Concentrations were 0.97 and 1.01 for parities 2 and $\geq 3$ fed CON, and 0.96 and 0.94 for parities 2 and $\geq 3$ fed BC. Concentration of urea $\mathrm{N}$ tended $(P=0.07)$ to be affected by a treatment by parity interaction, where urea $\mathrm{N}$ was 13.5 and $14.2 \mathrm{mg} / \mathrm{dL}$ for parity 2 and $\geq 3$ cows fed CON and 13.8 and $13.3 \mathrm{mg} / \mathrm{dL}$ for those fed
BC. Concentration of total protein was not affected by treatment. Total protein concentrations increased with increasing parity $(6.5$ vs. $6.7 \mathrm{~g} / \mathrm{dL}$ for parities 2 and $\geq 3$ ). A treatment by parity interaction was present $(P$ $<0.0001$ ) for albumin, in which concentrations were 3.16 and $3.34 \mathrm{~g} / \mathrm{dL}$ for parities 2 and $\geq 3$ fed CON and 3.20 and $3.08 \mathrm{~g} / \mathrm{dL}$ for parities 2 and $\geq 3$ fed BC. Concentration of globulin was affected by a treatment by parity interaction, wherein concentrations were 3.38 and $3.31 \mathrm{~g} / \mathrm{dL}$ for parity 2 and $\geq 3$ cows fed CON and 3.41 and $3.62 \mathrm{~g} / \mathrm{dL}$ for parities 2 and $\geq 3$ fed BC. Corresponding to these changes, the ratio of albumin to globulin was affected by a treatment by parity interaction $(P=0.0005)$; ratios were 0.97 and 1.05 for $\mathrm{CON}$ cows of parity 2 and $\geq 3$, respectively, and 0.97 and 0.86 for $\mathrm{BC}$ cows of parities 2 and $\geq 3$.

Serum concentrations of bilirubin and bicarbonate were not affected by treatments, but each was affected by parity. Bilirubin concentrations increased with increasing parity $(0.33$ and $0.44 \mathrm{mg} / \mathrm{dL}$ for parities 2 and $\geq 3$ ). Bicarbonate concentration decreased with increasing parity (19.6 and $18.6 \mathrm{mg} / \mathrm{dL}$ for parities 2 and $\geq 3$ ).

Calcium concentration was not affected by treatment, but decreased with increasing parity (9.01 and $8.83 \mathrm{mg} / \mathrm{dL}$ for parities 2 and $\geq 3$ ). Phosphorus was affected by a treatment by parity interaction $(P=$ $0.0008)$. Concentrations were 5.00 and $4.45 \mathrm{mg} / \mathrm{dL}$ for parity 2 and $\geq 3$ cows fed CON, and 4.78 and 5.00 for parity 2 and $\geq 3$ cows fed BC. Magnesium also was affected by a treatment by parity interaction $(P=0.01)$, wherein concentrations were 2.07 and $2.13 \mathrm{mg} / \mathrm{dL}$ for parity 2 and $\geq 3$ cows fed CON, and 2.11 and $2.00 \mathrm{mg} /$ $\mathrm{dL}$ for $\mathrm{BC}$ cows of parity 2 and $\geq 3$.

The concentration of $\mathrm{Na}$ was affected by treatment, wherein cows fed CON were 140.3 and those fed BC were $139.6 \mathrm{mmol} / \mathrm{L}$. Potassium was not affected by treatment, but was affected by parity (4.44 vs. 4.28 
Prom et al.: SUPPLEMENTAL $\beta$-CAROTENE DURING CLOSE-UP PERIOD

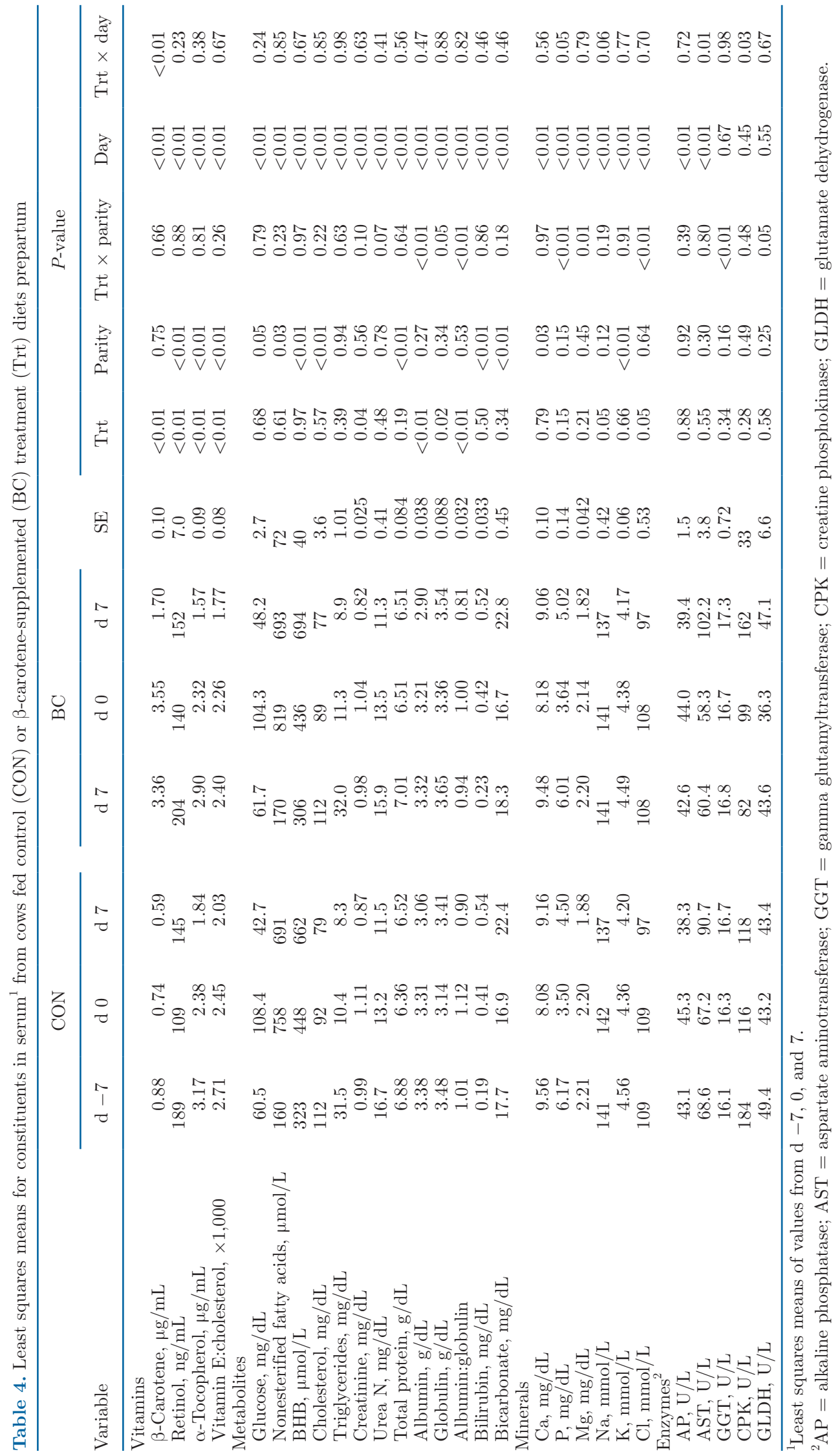


Table 5. Least squares means for production and reproduction for cows fed control (CON) or $\beta$-carotene-supplemented (BC) treatment diets prepartum

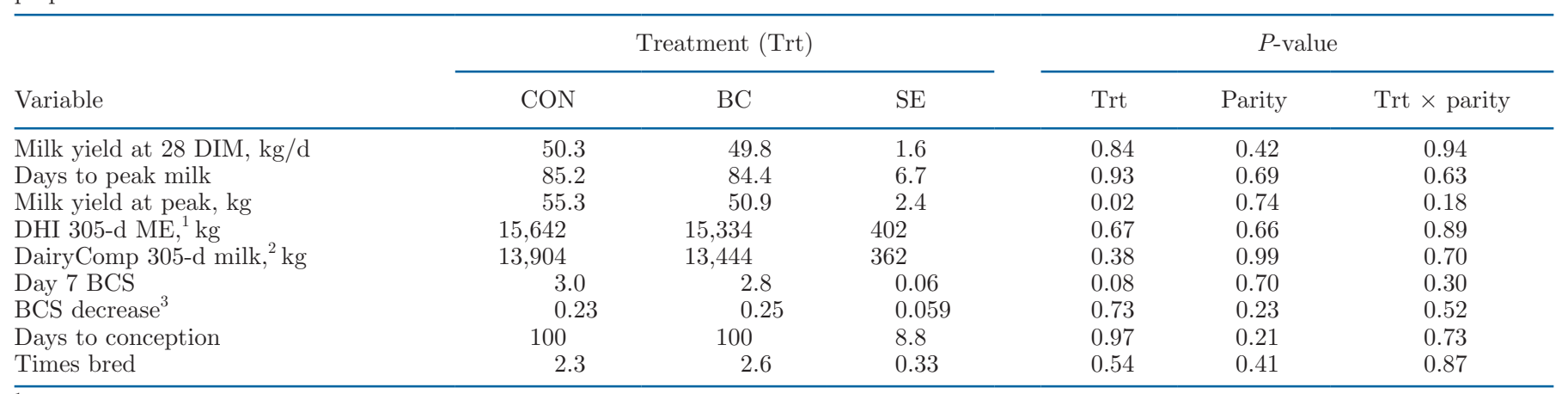

${ }^{1}$ Dairy Herd Improvement calculated 305-d mature equivalent milk yield.

${ }^{2}$ DairyComp actual 305-d milk yield for current lactation.

${ }^{3}$ Score at $-21 \mathrm{~d}$ relative to calving (before treatments) minus score at $7 \mathrm{~d}$ postpartum.

$\mathrm{mmol} / \mathrm{L}$ for parities 2 and $\geq 3$ ). Concentration of $\mathrm{Cl}$ was affected by a treatment by parity interaction $(P$ $=0.005$ ). Concentration of $\mathrm{Cl}$ was 104.6 and 105.7 $\mathrm{mmol} / \mathrm{L}$ for parity 2 and $\geq 3$ for cows fed CON, and 105.0 and $103.5 \mathrm{mmol} / \mathrm{L}$ for parity 2 and $\geq 3$ cows fed $\mathrm{BC}$.

Of the serum enzymes measured (Table 4), AP, AST, and creatine phosphokinase were not affected by treatment or parity. Activity of AST was affected by a treatment by day interaction (Table 4). Activity of GGT was affected by a treatment by parity interaction, whereby GGT was 18.1 and $14.7 \mathrm{U} / \mathrm{L}$ for CON cows of parity 2 and $\geq 3$, respectively, and 16.1 and $17.8 \mathrm{U} / \mathrm{L}$ for BC cows of parities 2 and $\geq 3$. Activity of GLDH was affected by a treatment by parity interaction, where activity was 53.8 and $36.9 \mathrm{U} / \mathrm{L}$ for CON cows of parity 2 and $\geq 3$, and 40.4 and $44.4 \mathrm{U} / \mathrm{L}$ for BC cows.

$\beta$-Carotene concentration had few correlations of note with other metabolites in cow serum. The strongest correlations were with vitamin $\mathrm{E}(\mathrm{r}=0.24, P<$ $0.01)$ and $\mathrm{AP}(\mathrm{r}=-0.27, P<0.01)$. $\beta$-Carotene had a weak correlation of $-0.14(P<0.01)$ with $\mathrm{BHB}$, but no correlation with NEFA. Vitamins A and E were moderately correlated $(\mathrm{r}=0.47, P<0.01)$. Vitamin A was moderately and negatively correlated with both NEFA and BHB at $\mathrm{r}=-0.63$ and $\mathrm{r}=-0.49(P<0.01$ for each), respectively, whereas vitamin $\mathrm{E}$ had correlations of -0.42 and $-0.48(P<0.01$ for each $)$ with NEFA and BHB.

\section{Cow Production, Health, and Reproduction}

The results for the continuous variables are shown in Table 5. Only peak milk yield was affected by treatment, where yield was greater for CON than for BC. No variables were affected by parity or treatment by parity interactions. Binomial health variable results are presented in Table 6 . No variables were found to have a significant effect of treatment. No cases of clinical milk fever occurred. Only 2 incidents of retained placenta were observed, both from $\mathrm{BC}$ cows. No cases of ketosis were detected by farm personnel, but 1 cow each in CON and BC groups had serum BHB >1,200 $\mu \mathrm{mol} / \mathrm{L}$, indicating the presence of subclinical ketosis.

\section{DISCUSSION}

The goal of this trial was to determine the effects of prepartal $\beta$-carotene supplementation using cows with adequate vitamin $\mathrm{A}$ and $\mathrm{E}$ supplementation but low $\beta$-carotene status from a herd with high milk production. Although much research has been done supplementing $\beta$-carotene to cows, some studies expected $\beta$-carotene to be used as provitamin $\mathrm{A}$, whereas another assumed it had non-provitamin A effects without accounting for the baseline $\beta$-carotene and vitamin status of the animals (Oliveira et al., 2015). Because of this variability, our study made a point of analyzing the vitamin and $\beta$-carotene concentrations of the feedstuffs and the serum of cows.

Serum $\beta$-carotene concentration before supplementation was quite low $(0.85 \mu \mathrm{g} / \mathrm{mL})$ compared with the proposed adequate serum $\beta$-carotene concentration of $3.0 \mu \mathrm{g} / \mathrm{mL}$ (Arbeiter et al., 1983). In contrast, serum concentrations of retinol and $\alpha$-tocopherol were at the low end of the adequate range (Kahn, 2010) and within the ideal range of 2 to $4 \mu \mathrm{g} / \mathrm{mL}$ (Weiss et al., 1997), respectively, for both treatment groups. Therefore, we achieved our goal of using cows with low $\beta$-carotene status but adequate vitamin $\mathrm{A}$ and $\mathrm{E}$ status.

Although the formulated concentration of vitamin A for both groups was quite high, it was far from the amount necessary to cause hypervitaminosis A (NRC, 2001; Combs, 2008). The adequate to high amounts of 
vitamin A fed should have allowed $\beta$-carotene to maximize its role as an antioxidant as it should not have been required as provitamin A. However, even with the dietary vitamin A exceeding the NRC (2001) requirements, serum retinol concentrations were increased by $\beta$-carotene supplementation. This significant treatment effect indicated that some $\beta$-carotene still was used as provitamin A. This finding highlighted the fact that serum vitamin concentrations should be checked in $\beta$-carotene research studies before drawing conclusions on the effects of $\beta$-carotene.

Even though some $\beta$-carotene was evidently converted to retinol in the small intestine, $\beta$-carotene concentrations in serum of the cows were still increased from an overall mean of $0.73 \mu \mathrm{g} / \mathrm{mL}$ in control cows to $2.87 \mu \mathrm{g} / \mathrm{mL}$ in supplemented cows. Cows supplemented with $\beta$-carotene achieved a mean peak serum concentration of $3.55 \mu \mathrm{g} / \mathrm{mL}$, whereas the cows that were not supplemented peaked at $0.88 \mu \mathrm{g} / \mathrm{mL}$. Concentrations of $\beta$-carotene in blood clearly respond to supplemental dietary $\beta$-carotene as shown in our study and in agreement with previous research (Arbeiter et al., 1983; Oliveira et al., 2015; Mary et al., 2021). The pattern of blood $\beta$-carotene decreasing during the dry period and being lowest soon after parturition has been well described (Weiss et al., 1994; Mary et al., 2021; Strickland et al., 2021). On the basis of studies that explored vitamin $\mathrm{A}$-independent effects of $\beta$-carotene supplementation on reproductive functions (Lotthammer and Ahlswede, 1977), Arbeiter et al. (1983) pro- posed that $\beta$-carotene concentrations in blood of $>3.0$ $\mu \mathrm{g} / \mathrm{mL}$ were normal, whereas concentrations $<1.0 \mu \mathrm{g} /$ $\mathrm{mL}$ were deficient. A value of $3 \mu \mathrm{g} / \mathrm{mL}$ has been widely used as an indicator of adequacy (Herdt and Stowe, 1991). Using this classification, our CON cows would be deficient, whereas $\mathrm{BC}$ cows would be adequate during supplementation. However, whether the classification of Arbeiter et al. (1983) is appropriate for determining adequacy of $\beta$-carotene in periparturient cows relative to health and production cannot be determined from available data.

$\beta$-Carotene supplementation decreased $\alpha$-tocopherol concentrations, both as absolute concentration and when expressed as a ratio to cholesterol to account for distribution into lipoproteins. Vitamin E concentrations in the diet and cow serum were adequate, but perhaps $\beta$-carotene competed with vitamin $\mathrm{E}$ for absorption or transport. Weiss et al. (1994) reported that supplemental vitamin $\mathrm{E}$ decreased plasma $\beta$-carotene in peripartal cows not fed supplemental fat.

Several metabolites, minerals, and enzymes showed parity effects and treatment by parity interactions, but absolute changes were small and of questionable biological significance. All values were within normal ranges. Although Aragona et al. (2021) found that BC decreased NEFA during the transition period, concentrations were not affected in our study.

Similar to our study, Oliveira et al. (2015) also supplemented $\beta$-carotene only prepartum and observed no effects on production or reproduction. Prepartum

Table 6. Cow health results for binomial variables related to reproduction and health for cows fed control (CON) or $\beta$-carotene-supplemented (BC) diets prepartum

\begin{tabular}{|c|c|c|c|c|c|c|}
\hline Variable & Risk factor & Coefficient & $\mathrm{SE}$ & $\mathrm{OR}^{1}$ & $95 \% \mathrm{CL}$ & $P$-value \\
\hline Sold 4,5 & Left the herd & -0.315 & 0.95 & 0.73 & 0.11 to 4.8 & 0.74 \\
\hline $\mathrm{DA}^{4,6}$ & Displaced abomasum incidence & -0.0002 & 0.74 & 1.0 & 0.23 to 4.3 & 0.99 \\
\hline Lame $^{4,8}$ & Lameness incidence & 0.989 & 0.86 & 2.7 & 0.48 to 15 & 0.26 \\
\hline Footrot $^{4,9}$ & Footrot incidence & -0.311 & 0.79 & 0.73 & 0.15 to 3.5 & 0.70 \\
\hline Mastitis ${ }^{4,10}$ & Clinical mastitis incidence & -0.77 & 1.2 & 0.46 & 0.039 to 5.5 & 0.54 \\
\hline
\end{tabular}

${ }^{1}$ Odds ratio for $\mathrm{BC}$ cows compared with CON cows. Ketosis, milk fever, and retained placentas were excluded because not enough incidents occurred to perform statistical analysis

${ }^{2}$ As of 120 DIM.

${ }^{3} \mathrm{n}=94$; pregnant (referent) $=70(38 \mathrm{CON}, 32 \mathrm{BC})$, bred and not pregnant $=12(5 \mathrm{CON}, 7 \mathrm{BC})$, not bred $=12(4 \mathrm{CON}, 8 \mathrm{BC})$.

${ }^{4}$ As of 30 DIM

${ }^{5} \mathrm{n}=94$; left herd (referent) $=5(3 \mathrm{CON}, 2 \mathrm{BC})$, not left $=89$.

${ }^{6} \mathrm{n}=94$; incidence of displaced abomasum (DA; referent) $=8$ (5 CON, $\left.3 \mathrm{BC}\right)$, no $\mathrm{DA}=86$.

${ }^{7} \mathrm{n}=94$; went off feed (referent) $=4(1 \mathrm{CON}, 3 \mathrm{BC})$, not off feed $=90$.

${ }^{8} \mathrm{n}=94$; incidence of lameness (referent) $=7(3 \mathrm{CON}, 4 \mathrm{BC})$, not lame $=87$.

${ }^{9} \mathrm{n}=94$; incidence of footrot (referent) $=7(5 \mathrm{CON}, 2 \mathrm{BC})$, no footrot $=87$.

${ }^{10} \mathrm{n}=94$; incidence of clinical mastitis (referent) $=3(2 \mathrm{CON}, 1 \mathrm{BC})$, no mastitis $=91$.

${ }^{11} \mathrm{n}=94$; incidence of metritis (referent) $=5(2 \mathrm{CON}, 3 \mathrm{BC})$, no metritis $=89$. 
supplementation of $\beta$-carotene decreased the incidence of retained placenta in that study, as well as in the study of Michal et al. (1994), but baseline incidence was much greater than in our study. Reproductive effects of $\beta$-carotene supplemented only prepartum have been modest (Kaewlamun et al., 2011). Studies that observed positive effects on reproduction generally supplemented $\beta$-carotene postpartum (de Ondarza et al., 2009), although not all studies demonstrated positive effects (Hurley and Doane, 1989).

This commercial dairy herd operated at high levels of productivity. In this environment and with high levels of vitamin A supplementation, supplementation of $\mathrm{BC}$ resulted in no effects on production, reproduction, or health, with the exception of lower peak milk yield, which was not reflected in lower full-lactation production. Strickland et al. (2021) reported a negative relationship between serum $\beta$-carotene and milk production in cows not supplemented with dietary $\beta$-carotene. Another study in which $\beta$-carotene was supplemented prepartum showed no effect on milk yield (Oliveira et al., 2015). Where supplemental $\beta$-carotene has increased milk yield (Aréchiga et al., 1998; Oldham et al., 1991), it has been supplemented postpartum. The lack of treatment response when investigating the health and reproduction data in our study may not be surprising as the power analysis for sample size was conducted on the basis of blood vitamin concentrations. A much larger sample size is needed to detect health and reproductive differences.

\section{CONCLUSIONS}

In a high-producing commercial dairy herd with adequate vitamin A status, $\beta$-carotene supplementation during the close-up period increased $\beta$-carotene and vitamin A concentrations in blood serum, but decreased vitamin E concentration. Supplementation of $\beta$-carotene prepartum had no effects on production, reproduction, or health.

\section{ACKNOWLEDGMENTS}

We thank DSM (Parsippany, NJ) for funding the experiment. We are indebted to the owners and employees of the commercial dairy farm (Fair Oaks, IN) for their cooperation in conducting this experiment. The authors have not stated any conflict of interest.

\section{REFERENCES}

Akar, Y., and A. Gazioglu. 2006. Relationship between vitamin A and $\beta$-carotene levels during the postpartum period and fertility parameters in cows with and without retained placenta. Bull. Vet. Inst. Pulawy 50:93-96.
Albera, E., and M. Kankofer. 2009. Antioxidants in colostrum and milk of sows and cows. Reprod. Domest. Anim. 44:606-611. https: //doi.org/10.1111/j.1439-0531.2007.01027.x.

Albera, E., and M. Kankofer. 2010. The comparison of antioxidative/ oxidative profile in colostrum, milk and blood of early post-partum cows during their first and second lactation. Reprod. Domest. Anim. 45:e417-e425. https://doi.org/10.1111/j.1439-0531.2010 .01592.x.

Aragona, K. M., E. M. Rice, M. Engstrom, and P. S. Erickson. 2021. Effect of $\beta$-carotene supplementation to prepartum Holstein cows on colostrum quality and calf performance. J. Dairy Sci. 104:88148825. https://doi.org/10.3168/jds.2020-19553.

Arbeiter, K., E. Knaus, and M. Thurnher. 1983. Repeat testing of genital function in cattle in relation to the beta-carotene level in blood. Zentralbl. Veterinarmed. A 30:206-213. https://doi.org/10 .1111/j.1439-0442.1983.tb00695.x.

Aréchiga, C. F., C. R. Staples, L. R. McDowell, and P. J. Hansen. 1998. Effects of timed insemination and supplemental beta-carotene on reproduction and milk yield of dairy cows under heat stress. J. Dairy Sci. 81:390-402. https://doi.org/10.3168/jds.S0022 $-0302(98) 75589-4$

Bernabucci, U., B. Ronchi, N. Lacetera, and A. Nardone. 2005. Influence of body condition score on relationships between metabolic status and oxidative stress in periparturient dairy cows. J. Dairy Sci. 88:2017-2026. https://doi.org/10.3168/jds.S0022 $-0302(05) 72878-2$.

Castillo, C., J. Hernandez, A. Bravo, M. Lopez-Alonso, V. Pereira, and J. L. Benedito. 2005. Oxidative status during late pregnancy and early lactation in dairy cows. Vet. J. 169:286-292. https://doi.org/ 10.1016/j.tvjl.2004.02.001

Chew, B. P. 1987. Vitamin A and $\beta$-carotene in host defense. J. Dairy Sci. 70:2732-2743. https://doi.org/10.3168/jds.S0022 -0302(87)80346-6.

Chew, B. P. 1993. Role of carotenoids in the immune response. J. Dairy Sci. 76:2804-2811. https://doi.org/10.3168/jds.S0022 -0302(93)77619-5.

Chew, B. P., L. Hollen, J. Hillers, and M. Herlugson. 1982. Relationship between vitamin A and $\beta$-carotene in blood plasma and milk and mastitis in Holsteins. J. Dairy Sci. 65:2111-2118. https://doi .org/10.3168/jds.S0022-0302(82)82469-7.

Chew, B. P., and J. S. Park. 2004. Carotenoid action on the immune response. J. Nutr. 134:257S-261S. https://doi.org/10.1093/jn/134 $.1 .257 \mathrm{~S}$.

Combs, G. F. 2008. The Vitamins: Fundamental Aspects in Nutrition and Health. 3rd ed. Elsevier Academic Press.

de Ondarza, M. B., J. W. Wilson, and M. Engstrom. 2009. Case study: Effect of supplemental $\beta$-carotene on yield of milk and milk components and on reproduction of dairy cows. Prof. Anim. Sci 25:510-516. https://doi.org/10.15232/S1080-7446(15)30742-7.

Drackley, J. K. 1999. Biology of dairy cows during the transition period: The final frontier? J. Dairy Sci. 82:2259-2273. https://doi .org/10.3168/jds.S0022-0302(99)75474-3.

Ferguson, J. D., D. T. Galligan, and N. Thomsen. 1994. Principal descriptors of body condition score in Holstein cows. J. Dairy Sci 77:2695-2703. https://doi.org/10.3168/jds.S0022-0302(94)77212 $-X$.

Goff, J. P., and R. L. Horst. 1997. Physiological changes at parturition and their relationship to metabolic disorders. J. Dairy Sci 80:1260-1268. https://doi.org/10.3168/jds.S0022-0302(97)76055 -7 .

Herdt, T. H., and H. D. Stowe. 1991. Fat-soluble vitamin nutrition for dairy cattle. Vet. Clin. North Am. Food Anim. Pract. 7:391-415. https://doi.org/10.1016/S0749-0720(15)30796-9.

Horst, E. A., S. K. Kvidera, and L. H. Baumgard. 2021. Invited review: The influence of immune activation on transition cow health and performance - A critical evaluation of traditional dogmas. J. Dairy Sci. 104:8380-8410. https://doi.org/10.3168/jds.2021-20330.

Hurley, W. L., and R. M. Doane. 1989. Recent developments in the roles of vitamins and minerals in reproduction. J. Dairy Sci. 72:784-804. https://doi.org/10.3168/jds.S0022-0302(89)79170-0. 
Inaba, T., A. Inoue, R. Shimizu, Y. Nakano, and J. Mori. 1986. Plasma concentrations of progesterone, estrogens, vitamin A and beta-carotene in cows retaining fetal membranes. Nippon Juigaku Zasshi 48:505-508. https://doi.org/10.1292/jvms1939.48.505.

Jukola, E., J. Hakkarainen, H. Saloniemi, and S. Sankari. 1996. Blood selenium, vitamin $\mathrm{E}$, vitamin $\mathrm{A}$, and $\beta$-carotene concentrations and udder health, fertility treatments and fertility. J. Dairy Sci. 79:838-845. https://doi.org/10.3168/jds.S0022-0302(96)76432-9.

Kaewlamun, W., M. Okouyi, P. Humblot, M. Techakumphu, and A. A. Ponter. 2011. Does supplementing dairy cows with $\beta$-carotene during the dry period affect postpartum ovarian activity, progesterone, and cervical and uterine involution? Theriogenology 75:10291038. https://doi.org/10.1016/j.theriogenology.2010.11.010.

Kahn, C. M. 2010. The Merck Veterinary Manual: Feeding and Nutritional Management of Dairy Cattle. Merck \& Co., Inc.

Kawashima, C., K. Kida, F. J. Schweigert, and A. Miyamoto. 2009. Relationship between plasma $\beta$-carotene concentrations during the peripartum period and ovulation in the first follicular wave postpartum in dairy cows. Anim. Reprod. Sci. 111:105-111. https:// doi.org/10.1016/j.anireprosci.2008.02.008

LeBlanc, S. J., T. H. Herdt, W. M. Seymour, T. F. Duffield, and K. E. Leslie. 2004. Peripartum serum vitamin E, retinol, and beta-carotene in dairy cattle and their associations with disease. J. Dairy Sci. 87:609-619. https://doi.org/10.3168/jds.S0022-0302(04)73203 -8 .

Lotthammer, K. H., and L. Ahlswede. 1977. Specific vitamin A-independent effect of beta-carotene on the bovine fertility. 3. Analysis of blood serum levels (beta-carotene, vitamin A, SGOT, total cholesterol, glucose, inorganic phosphorus). Dtsch. Tierarztl. Wochenschr. 84:220-226.

Lykkesfeldt, J., and O. Svendsen. 2007. Oxidants and antioxidants in disease: Oxidative stress in farm animals. Vet. J. 173:502-511. https://doi.org/10.1016/j.tvjl.2006.06.005.

Machlin, L. J., and A. Bendich. 1987. Free radical tissue damage: Protective role of antioxidant nutrients. FASEB J. 1:441-445. https:/ /doi.org/10.1096/fasebj.1.6.3315807.

Mary, A. E. P., J. I. Artavia Mora, P. A. Ronda Borzone, S. E. Richards, and A. K. Kies. 2021. Vitamin E and beta-carotene status of dairy cows: A survey of plasma levels and supplementation practices. Animal 15:100303. https://doi.org/10.1016/j.animal.2021 .100303 .

Michal, J. J., L. R. Heirman, T. S. Wong, B. P. Chew, M. Frigg, and L. Volker. 1994. Modulatory effects of dietary $\beta$-carotene on blood and mammary leukocyte function in periparturient dairy cows. J. Dairy Sci. 77:1408-1421. https://doi.org/10.3168/jds.S0022 -0302(94)77079-X.

NRC. 2001. Nutrient Requirements of Dairy Cattle. 7th rev. ed. National Academy Press.

Oldham, E. R., R. J. Eberhart, and L. D. Muller. 1991. Effects of supplemental vitamin $\mathrm{A}$ or $\beta$-carotene during the dry period and early lactation on udder health. J. Dairy Sci. 74:3775-3781.

Oliveira, R. C., B. M. Guerreiro, N. N. Morais Junior., R. L. Araujo, R. A. Pereira, and M. N. Pereira. 2015. Supplementation of prepartum dairy cows with $\beta$-carotene. J. Dairy Sci. 98:6304-6314. https://doi.org/10.3168/jds.2014-9037.

Strickland, J. M., L. Wisnieski, T. H. Herdt, and L. M. Sordillo. 2021. Serum retinol, $\beta$-carotene, and $\alpha$-tocopherol as biomarkers for disease risk and milk production in periparturient dairy cows. J. Dairy Sci. 104:915-927. https://doi.org/10.3168/jds.2020-18693.

Weiss, W. P., J. Hogan, D. Todhunter, and K. Smith. 1997. Effect of vitamin $\mathrm{E}$ supplementation in diets with a low concentration of selenium on mammary gland health of dairy cows. J. Dairy Sci. 80:1728-1737. https://doi.org/10.3168/jds.S0022-0302(97)76105 -8 .

Weiss, W. P., J. S. Hogan, K. L. Smith, and S. N. Williams. 1994. Effect of dietary fat and vitamin $\mathrm{E}$ on $\alpha$-tocopherol and $\beta$-carotene in blood of peripartum cows. J. Dairy Sci. 77:1422-1429. https:// doi.org/10.3168/jds.S0022-0302(94)77080-6.

\section{ORCIDS}

C. M. Prom () https://orcid.org/0000-0003-0921-5529

M. A. Engstrom ® https://orcid.org/0000-0003-0959-9390

J. K. Drackley ๑ https://orcid.org/0000-0002-4560-5594 